\title{
SIKAP DAN PERILAKU KONSUMEN TERHADAP NATIVE ADVERTISING
}

\author{
Siti Aisyah \\ Universitas Islam Negeri Sumatera Utara Medan \\ siti.aisyah@uinsu.ac.id
}

\begin{abstract}
The marketing strategy continues to develop. Internet advertising is commonly referred to as e-marketing. Various e-marketing strategies can be done now, for example online advertising. Advertising that used to be offline is now utilizing the internet. One of the formats for online advertising is native ad. Native advertising is a digital advertising format that is still relatively new for online advertising. This study aims to explain how native advertising is used and see how consumers' attitudes towards evaluating native ads. It is recommended to see more than where the original ad can be effectively approved according to marketing objectives. This research uses descriptive analysis technique with random sampling data collection techniques to 420 respondents online. Obtained results from native advertisements that are supported and able to produce positive attitudes and behaviors that benefit marketers or ad owners. Respond to native ads that can provide good information, fun, useful, credible, and do not disturb.
\end{abstract}

Keywords: behavior, belief, e-marketing, online advertising, native advertising

\begin{abstract}
Abstrak
Strategi pemasaran terus berkembang sejalan dengan perkembangan teknologi internet. Biasanya periklanan dengan internet disebut sebagai e-marketing. Berbagai strategi e-marketing dapat dilakukan saat ini, contohnya adalah online advertising. Periklanan yang semula menggunakan bedia offline kini memanfaatkan internet. Adapun salah satu format online advertising yaitu native advertising. Native advertising merupakan format digital advertising yang masih tergolong baru untuk periklanan online. Penelitian ini bertujuan untuk memaparkan bagaimana native advertising digunakan serta melihat bagaimana sikap dan perilaku konsumen dalam menilai native advertising. Hal ini bertujuan untuk melihat sejauh mana native advertising dapat dinilai efektif dalam menyampaikan tujuan pemasaran. Penelitian ini menggunakan teknik analisis deskriptif dengan teknik pengumpulan data random sampling kepada 420 orang responden online. Diperoleh hasil bahwa native advertising dipercaya dan mampu memnghasilkan sikap dan perilaku positif yang menguntungkan pemasar atau pemilik iklan. Responden menganggap native advertising dapat memberikan informasi yang baik, menghibur, bermanfaat, kredibel dan tidak mengganggu.
\end{abstract}

Kata Kunci: iklan online, iklan native, kepercayaan, pemasaran online, perilaku

\section{Pendahuluan}

Penggunaan internet, media digital dan perkembangan teknologi untuk mendukung pemasaran modern turut memunculkan berbagai istilah baru dalam 
pemasaran, diantaranya, yaitu digital marketing, internet marketing, web marketing dan e-marketing. Pemasaran internet (e-marketing) semakin berkembang dan dibutuhkan oleh pemasar. Periklanan atau iklan (ads) merupakan salah satu strategi unggulan yang digunakan oleh pemasar dalam melakukan kegiatan pemasaran. Perkembangan penggunaan internet juga turut merubah strategi periklanan. Semula, periklanan dilakukan secara konvensional (offiline) seperti menggunakan banner, baliho, flyer, dan sebagainya. Namun, kini periklanan internet (online) lebih diminati. Hal ini terlihat dari meningkatnya jumlah belanja iklan digital dari tahun ke tahun. Pada tahun 2019, berdasarkan laporan Nielsen belanja iklan digital di Indonesia menyumbang 6\% dari total belanja iklan di Indonesia yakni sebesar Rp9,3 triliun. ${ }^{1}$

Berbagai format iklan digital atau digital advertising (digital ads) juga terus dikembangkan. Salah satu yang populer adalah format banner ads dan video ads. Beberapa penelitian dan laporan periklanan penyebutkan ada format digital ads baru, yaitu native ads. The Interactive Advertising Bureau (IAB) yang merupakan sebuah organisasi periklanan dunia mengembangkan standar industri periklanan, melakukan penelitian dan menyediakan dukungan hukum bagi industri periklanan memberikan definisi native ads adalah "paid adverts that are cohesive with the page content, assimilated into the design, and consistent with the platform behavior that the viewer simply feels that they belong. ${ }^{2}$ Native ads mulai diperbincangkan oleh pemasar dan publisher sekitar tahun 2012, dan semakin populer digunakan pada tahun 2013-2014 dengan ditandai keberhasilan kampanye Netflix melalui media The New York Times. Ketika itu, Netflix mengkampanyekan serial "Orange Is The New Black" melalui artikel sponsor menggunakan 1.500 kata berjudul "Women Inmates: Why The Male Model Does't Work" yang lebih terlihat seperti laporan jurnalis daripada sebuah iklan, dan hasilnya menyebutkan bahwa iklan ini populer di media The New York Times. ${ }^{3}$

Kepopuleran native ads menyebar hingga ke Indonesia. Di Indonesia, pengiklan dan media menyebut format ini sebagai iklan yang tampil seperti berita dengan tampilan yang sama dengan media aslinya atau menyatu dengan latar media yang digunakan. Beberapa istilah yang digunakan untuk menfesinisikan native ads antara lain, yaitu "Sponsored Content, Paid Post, Branded Content, Partner Conten 
dan sebagainya. Jika mengkaji tujuan iklan yaitu untuk mengkomunikasikan pesanpesan dari perusahaan kepada target audien dengan tujuan tertentu maka native ads menurut Yaveroglu dan Naveen dapat menjadi format digital ads masa depan yang lebih efektif dari display ads lainnya karena lebih diterima oleh audience dan konsumen dinilai lebih memperhatikan native ads daripada iklan biasa. ${ }^{4}$

Selanjutnya, kesuksessan sebuah pemasaran atau iklan dapat dinilai dari bagaimana konsumen menerima iklan tersebut, bagaimana mereka mempersepsikan iklan sehingga dapat diketahui bagaimana mereka akan berperilaku terhadap iklan tersebut. Kotler ${ }^{5}$ menjelaskan "the most important way of understanding users and their perceptions and acceptance of advertising messages is by studying attitudes". 6 Selain itu, Ducoffee ${ }^{7}$ dan Russell ${ }^{8}$ menilai bahwa kepercayaan konsumen (belief) dan perilaku (behavior) juga merupakan tolak ukur penting dalam menilai efektifitas iklan. $^{9}$

Berdasarkan fenomena tersebut, penelitian ini ingin melihat sejauh mana native ads dapat diterima oleh target audien dan faktor-faktor apa saja yang membuat native ads lebih diterima oleh target audience. Penelitian ini menggunakan landasan teori dalam menilai efektifitas iklan yakni faktor-faktor kepercayaan terhadap iklan berpengaruh terhadap sikap dan perilaku terhadap iklan.

\section{Kajian Literatur}

\section{Pemasaran Internet (E-Marketing)}

E-Marketing atau sering disebut internet marketing menurut Chaffey, yaitu "The application of the internet and related digital technologies to achieve marketing objective and support the modern marketing concept". ${ }^{10}$ Seiring perkembangan teknologi internet, kini istilah e-marketing lebih dikenal dengan istilah digital marketing. Menurut Chaffey dan Ellis-Chadwick, digital marketing adalah pengaplikasian internet dan teknologi digital pada komunikasi pemasaran tradisional untuk mencapai tujuan pemasaran atau secara sederhana dapat diartikan bahwa digital marketing adalah pencapaian tujuan pemasaran melalui pemanfaatan teknologi dan media digital. ${ }^{11}$

\section{Online Advertising}


Wells, Burnett dan Moriarty mendefinisikan ilklan sebagai salah satu alat promosi yang digunakan perusahaan untuk memasarkan produknya. ${ }^{12}$ Pada dasarnya pengertian iklan adalah "paid non personal communication from an identified sponsor using mass media to persuade or influence an audience”. Selain itu, iklan juga merupakan bentuk pesan tentang suatu produk yang disampaikan lewat media, ditujukan kepada sebagian atau seluruh masyarakat. ${ }^{13}$ Perkembangan internet juga turut merubah strategi pemasaran. Pemasar kini juga menggunakan internet sebagai sarana atau media dalam beriklan. Beberapa istilah seperti internet advertising atau online advertising atau digital advertising kini sering digunakan untuk menggambarkan kegiatan beriklan melalui internet. Louisa Ha dalam penelitiannya memberikan definisi tentang online advertising yaitu "as deliberate message placed on third party web site including search engines and directories available through internet access". Definisi lain menyebutkan bahwa online advertising adalah bentuk promosi yang menggunakan internet dan www untuk tujuan mengirimkan pesan pemasaran yang menarik pelanggan. ${ }^{14}$

Dapat disimpulkan bahwa online advertising adalah pesan yang sengaja dikirimkan (delebrate message) oleh pengirim pesan (perusahaan) melalui pihak ketiga (third party). Artinya, melalui definisi ini kita mengetahui bahwa informasi berupa promosi atau non-promosi yang disampaikan melalui website perusahaan itu sendiri, e-mail perusahaan tidak termasuk ke dalam definisi online advertising.

\section{Native Advertising}

Secara etimologi disebutkan bahwa native ads pertama kali dibicarakan oleh seorang investor bernama Fred Wilson ${ }^{15}$ yang disampaikan kepada OMMA Global pada akhir September 2011. Wilson pada saat itu tidak menggunakan istilah "native ads" melainkan menyebutnya dengan istilah "native monetization" untuk atribut dalam web, yang diartikan sebagai iklan yang unik dan memiliki pengalaman langsung atau asli dari sebuah website. ${ }^{16}$

Kemudian, pengertian native ads terus berkembang. Native ads merupakan kolaborasi antara pemilik merek dengan pemilik situs website yang menempatkan iklan di antara konten editorial lainnya. ${ }^{17}$ Campbell dan Marks memberikan pengertian native ads sebagai berikut: "Native ads is a term used to describe a 
spectrum of a new online advertising forms that share a focus on minimizing disruption to a consumer's online experience by appearing in-stream" artinya, native ads dimaksudkan untuk mengurangi gangguan pada pengalaman konsumen pada media online dengan cara memberikan tampilan sesuai medianya. ${ }^{18}$ Pada jurnal yang berjudul "Native Advertising: The Old Is New Again" dijelaskan bahwa native ads merupakan konten yang disponsori dan didesain agar sesuai dengan konten editorial dimana iklan tersebut ditempatkan. Adapun beragam teknik dan format yang termasuk dalam native ads menurut Seligman antara lain yaitu: ${ }^{19}$

\section{Custom content}

\section{Content that appears in-feed}

\section{Content that appears in a recommendation}

Adapun pengertian native ads yang umum dapat diambil dari acuan IAB, yaitu "Paid ads that are so cohesive with the page content, assimilated into the design, and consistent with the flatform behavior that viewer simply feels that they belong". Dengan kata lain dapat diartikan bahwa native ads adalah iklan berbayar yang secara desain, penempatan bersifat sama dengan konten dasar dalam website tersebut sehingga audiens menilai iklan tersebut sebagai konten biasa (bukan iklan).

\section{Dimensi Kepercayaan dan Sikap Terhadap Iklan Online}

Peter dan Olson menyebutkan bahwa iklan dimaksudkan untuk mempengaruhi afeksi dan kognisi konsumen, evaluasi perasaan, pengetahuan, makna, kepercayaan, sikap, dan citra konsumen menyangkut produk dan merek. Bahkan iklan dicirikan sebagai pengolahan citra, menciptakan dan mempertahankan citra dan makna di benak konsumen. Walaupun terlebih dahulu mempengaruhi afeksi dan kognisi, tujuan akhir iklan adalah mempengaruhi perilaku pembelian konsumen. ${ }^{20}$ Lebih lanjut Peter dan Olson memberikan pengertian bahwa sikap konsumen terhadap iklan sebagai evaluasi efektif konsumen terhadap iklan itu sendiri, mempengaruhi sikapnya terhadap produk atau merek yang diiklankan. Artinya, iklan yang disukai konsumen tampaknya menciptakan sikap merek yang lebih positif dan niat pembelian daripada iklan yang tidak disukai. ${ }^{21}$ 
Pollay dan Mittal membedakan antara kepercayaan dengan sikap dimana kepercayaan merupakan pernyataan deskriptif tentang atribut suatu objek sedangkan sikap merupakan ringkasan evaluasi terhadap suatu. Mahmoud mendefinisikan kepercayaan terhadap iklan internet sebagai seluruh pengetahuan yang oleh seseorang dapat dianggap benar untuk iklan internet. Sedangkan secara umum sikap (attitude) mengacu kepada kecenderungan kognitif positif atau negatif seseorang kepada suatu rujukan. Lutz mendefinisikan sikap terhadap iklan secara umum sebagai sebuah pembelajaran terhadap kecenderungan dalam merespons hal-hal yang menguntungkan dan tidak menguntungkan dari iklan. Adapun dalam konteks internet, Mahmoud mengartikan sikap terhadap iklan internet sebagai kecenderungan umum untuk suka atau tidak suka terhadap pesan iklan yang disampaikan secara online.

Pengertian kepercayaan (beliefs) menurut Eagly dan Chaiken, yaitu "Beliefs are typically conceptualized as estimates of the likelihood that the knowledge one has acquired about a referent is correct or, alternatively, that an event or state of affairs has or will occur."22 Mehta menyebutkan bahwa kepercayaan dan sikap konsumen terhadap iklan merupakan indikator terpenting dalam menilai efektivitas iklan.

Sedangkan Pollay dan Mittal mengklasifikasikan 7 (tujuh) faktor-faktor yang mendasari kepercayaan dan sikap konsumen terhadap iklan yang dibagi menjadi 2 (dua) kategori, yaitu:

The first category, labeled as personal use, consists of factors including product information, social role and image, and hedonic/pleasure. The second category, labeled as social effect, includes value corruption, falsity/no sense, good for the economy, and materialism". ${ }^{23}$

Di antara tujuh faktor, Belch menyebutkan bahwa informasi produk menggambarkan peran iklan sebagai pemasok informasi terpenting, yang memberikan kontribusi untuk efisiensi pasar. Ada beberapa faktor atau indikator yang mempengaruhi kepercayaan terhadap iklan internet (beliefs about internet advertising) yang dirangkum oleh Mahmoud, yaitu: informasi (information), hiburan (entertainment), gangguan (irritation), gaya hidup (social rule), materialism (materialism), kepalsuan (falsity) dan korupsi nilai-nilai (value corruption). Ducoffe juga menjelaskan bahwa nilai-nilai dari iklan tergantung kepada tingkat hiburan 
210 AT-TAWASSUTH: Jurnal Ekonomi Islam, Volume V No. 1

Januari - Juni 2020: 204 - 225

(entertainment), informatif (informativeness), dan gangguan (irritation) yang dirasakan. Penelitian yang dilakukan oleh Ling menyimpulkan bahwa pesan iklan yang dapat dipercaya atau masuk akal (credible), informatif (informative), nyaman atau menyenangkan (pleasurable), dan pasti baik (usefulness) bagi perekonomian yang diidentifikasi dengan perilaku pembelian terhadap iklan. ${ }^{24}$ Penelitian yang dilakukan oleh Ling menyimpulkan bahwa pesan iklan yang dapat dipercaya atau masuk akal (credible), informatif (informative), nyaman atau menyenangkan (pleasurable), dan pasti baik (usefulness) bagi perekonomian yang diidentifikasi dengan perilaku pembelian terhadap iklan. ${ }^{25}$

Ducoffe menemukan bahwa informatif (informativeness) dan hiburan (entertainment) berhubungan secara positif atau positively related kepada sikap atau perilaku terhadap iklan online (attitudes toward online advertising or ATOA. Kemudian Wolin menguji model kepercayaan Pollay dan Mittal dan menunjukkan bahwa beberapa faktor kepercayaan menyebabkan sikap pengguna web terhadap iklan online yang mana memiliki dampak pada perilaku pengguna $w e b .^{26}$

Lebih lanjut hal ini diilustrasikan oleh fakta bahwa sikap yang kuat merupakan hasil dari objek yang berhubungan dengan pribadi konsumen. Studi tersebut menunjukkan bahwa sikap positif terhadap iklan dapat membuat pesan dalam iklan tersebut lebih baik dan lebih efektif bagi konsumen dan hal ini memiliki implikasi penting bagi industri periklanan sehingga hal ini menunjukkan bahwa iklan yang mengandung konten informatif, jujur dan menghibur dapat mendorong konsumen untuk menyukai dan mempercayai iklan tersebut. Fakta bahwa native advertising menawarkan konten yang informatif dan sejalan dengan editorial dapat menjadi penjelasan yang memungkinkan timbulnya sikap positif terhadap native advertising. ${ }^{27}$

\section{Behavioral Responses Toward Online Advertising}

Mengutip MacKenzie, para peneliti sering menggunakan ATOA sebagai pengukuran tentang bagaimana konsumen bereaksi terhadap pesan-pesan komersial, seperti mengukur perasaan konsumen apakah suatu iklan menguntungkan atau tidak menguntungkan, baik iklan produk maupun iklan jasa. Penelitian lainnya yang dilakukan oleh Mehta menunjukkan bahwa terdapat hubungan yang kuat antara ATOA dan perilaku terhadap iklan online, dengan kata lain sikap positif terhadap 
iklan internet akan disertai dengan respons konsumen yang menguntungkan terhadap iklan internet tersebut begitu juga sebaliknya. ${ }^{28}$

\section{Metode Penelitian}

Jenis penelitian ini adalah kuantitatif deskriptif verifikatif. Penelitian kuantitatif adalah penelitian ilmiah yang mengkaji permasalah melalui fenomena serta bertujuan untuk melihat bagaimana hubungan antar variable dalam permasalah yang dikaji.29 Metode deskriptif digunakan untuk menggambarkan karakteristik objek, sample dan hasil penelitian. Metode verifikatif digunakan untuk menguji hipotesis dengan menggunakan perhitungan data statistik. Populasi dalam penelitian ini adalah pengguna internet aktif di Indonesia yang menghabiskan waktu lebih dari 2 jam per hari untuk menggunakan internet dan mereka yang pernah mendapatkan native ads selama mereka mengunakan internet. Dalam mengumpulkan data, penelitian ini menggunakan prosedur random sampling dan preliminary prescreening.

Penelitian ini merupakan penelitian cros sectional yang dibatasi oleh waktu dan frekuensi tertentu. Pengumpulan data dilakukan dengan menyebarkan online survey melalui google form dimana sebelumnya telah dilakukan definisi konsep variabel, dimensi variabel, indikator, tolak ukur dan skala yang akan digunakan. Survey yang dibagikan terdiri dari 2 bagian, yaitu bagian pertama merupakan kumpulan pertanyaan untuk mengumpulkan data demografi responden dan juga sebagai screening untuk menentukan responden termasuk sebagai populasi penelitian ini atau tidak. Bagian kedua didesain untuk mengetahui bagaimana perilaku konsumen Indonesia dalam menerima native ads yang akan diukur dengan menggunakan teori kepercayaan (belief) terhadap iklan berpengaruh kepada sikap (attitude) dan perilaku (behavior) terhadap iklan, bagaimana bagaimana potensi native ads dalam industri periklanan di Indonesia serta mengukur apakah adsblock di Indonesia banyak digunakan atau tidak.

Uji validitas dan realibilitas digunakan untuk menguji apakah data yang dikumpulkan valid dan dapat diukur. Lebih lanjut, karena penelitian ini merupakan penelitian modifikasi dari penelitian-penelitian sebelumnya, maka penelitian ini harus menguji model yang digunakan yakni dengan menggunakan analisis multivarian 
terhadap variabel yang independen (belief variabel) dan variabel dependen (attitude variabel dan behavior wariable). Berikut adalah konsep kerangka pemikiran dalam penelitian ini:

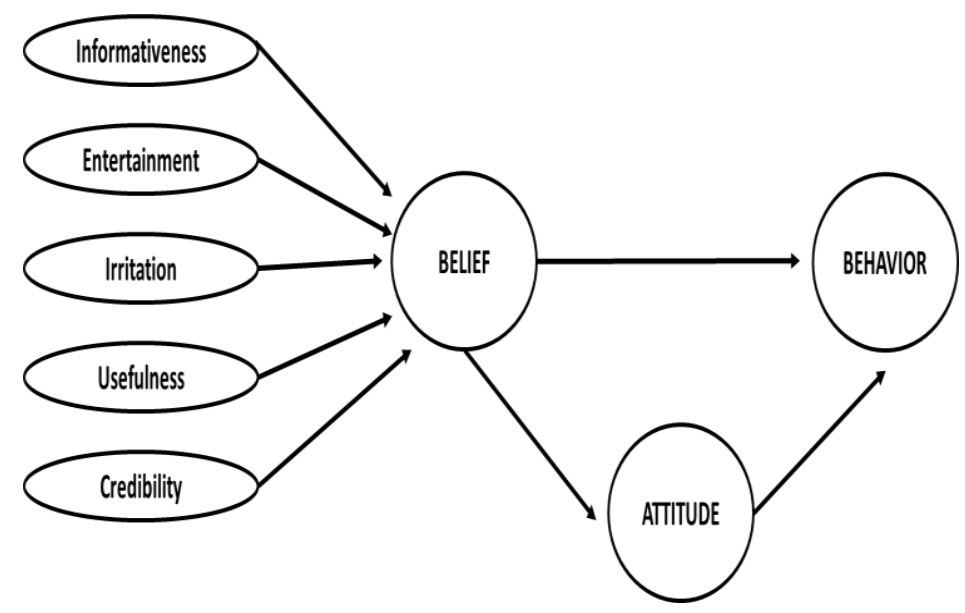

Gambar 1. Kerangka Teori

Sumber: Pengolahan data, 2019.

Analisis regresi berganda juga digunakan dalam penelitian ini untuk melihat hubungan antara 2 (dua) atau lebih wariabel independen terhadap variabel dependen secara bersamaan. Penelitian ini menggunakan Partial Least Square-Structural Equation Modeling (PLS-SEM) untuk menganalisa data dan mengunakan bantuan software analisis data SmartPLS 2.0. Pengolahan data dilakukan dengan multiple regression analysis. Uji hipotesa dilakukan dengan Uji Simultan (Uji F) untuk melihat keberpengaruhan setiap variabel bebas terhadap variable terikat, dan Uji Parsial (Uji t) dilakukan untuk melihat sejauh mana signifikansi pengaruh variabel bebas terhadap variabel terikat.

\section{Hasil dan Pembahasan}

Data yang berhasil dikumpulkan adalah 420 data. Sebanyak 400 data dapat dianalisa dan selanjutnya dilakukan pengujian data. Berikut adalah uraian deskripsi tabulasi data yang telah dikumpulkan. Tabel 1 tentang demografi responden memperlihatkan klasifikasi responden berdasarkan jenis kelamin, usia, pekerjaan, lamanya menghabiskan waktu per hari untuk menggunakan internet dan pengetahuan dasar responden terhadap native ads. 
Tabel 1 Demografi Responden

\begin{tabular}{|c|c|c|c|}
\hline $\begin{array}{c}\text { Demographic } \\
\text { Variables }\end{array}$ & Categories & Total & $\begin{array}{c}\text { Percentage } \\
(\%)\end{array}$ \\
\hline \multirow{3}{*}{ Gender } & Male & 170 & $42.5 \%$ \\
\cline { 2 - 4 } & Female & 230 & $57.5 \%$ \\
\hline \multirow{4}{*}{ Age } & $18-22$ & 140 & $35 \%$ \\
\cline { 2 - 4 } & $23-27$ & 138 & $34.5 \%$ \\
\cline { 2 - 4 } & $28-32$ & 77 & $19.25 \%$ \\
\hline \multirow{4}{*}{ Profession } & $33-37$ & 45 & $11.25 \%$ \\
\cline { 2 - 4 } & Students & 55 & $14 \%$ \\
\cline { 2 - 4 } & Employee & 238 & $59 \%$ \\
\cline { 2 - 4 } & Enterpreneur & 67 & $17 \%$ \\
\cline { 2 - 4 } & Professional & 25 & $6 \%$ \\
\cline { 2 - 4 } & Housewife & 11 & $3 \%$ \\
\hline \multirow{4}{*}{ Time for } & Others & 4 & $9 \%$ \\
\hline Internet & 2 jam & 36 & $23.25 \%$ \\
\cline { 2 - 4 } & $3-4$ jam & 93 & $28.75 \%$ \\
\cline { 2 - 4 } & $4-5$ jam & 115 & $39 \%$ \\
\cline { 2 - 4 } & $>5$ jam & 156 & \\
\hline
\end{tabular}

Sumber: Pengolahan data, 2019.

Berdasarkan hasil pengolahan data, terlihat bahwa mayoritas responden adalah wanita $(57.5 \%)$, rata-rata usia 28-27 tahun sebanyak 34.5\%. Dalam penelitian ini mayoritas responden berprofesi sebagai pegawai yakni sebanyak 238 responden (59\%). Adapun lamanya waktu yang digunakan responden untuk menggunakan internet dalam sehari adalah lebih dari 5 jam. Responden dapat melanjutkan ke tahap pertanyaan selanjutnya jika responden mengetahun atau pernah melihat iklan jenis native ads saat menggunakan internet. Dari total 420 responden yang mengikuti survey sebanyak 331 (82\%) responden yang mengetahui native ads.

Selanjutnya, dilakukan rekapitulasi tanggapan responden terhadap variabel belief, attitude dan behavior pada display ads yang mengacu kepada kriteria presentasi skor dalam lima tingkatan, yaitu:

1. $20,00 \%-36,00 \%$ level Sangat Tidak Baik

2. $36,01 \%-52,00 \%$ level Tidak Baik

3. $52,01 \%-68,00 \%$ level Cukup Baik

4. $68,01 \%-84,00 \%$ level Baik

5. $84,01 \%-100 \%$ level Sangat Baik 
214 |AT-TAWASSUTH: Jurnal Ekonomi Islam, Volume V No. 1

Januari - Juni 2020: 204 - 225

Tabel 2 Rekapitulasi Tanggapan Responden Terhadap Native Ads

Melalui Variabel Belief

\begin{tabular}{|l|c|c|c|c|c|}
\hline \multicolumn{1}{|c|}{ Indikator } & $\begin{array}{c}\text { Total Item } \\
\text { Pernyatan }\end{array}$ & $\begin{array}{c}\text { Total Skor } \\
\text { Aktual }\end{array}$ & $\begin{array}{c}\text { Total } \\
\text { Skor Ideal }\end{array}$ & Persentase & Kriteria \\
\hline Informativeness & 4 & 6020 & 8040 & $74,87 \%$ & Baik \\
\hline Usefulness & 2 & 3057 & 4020 & $76,04 \%$ & Baik \\
\hline Entertainment & 4 & 5808 & 8040 & $72,23 \%$ & Baik \\
\hline Credibility & 2 & 2733 & 4020 & $67,98 \%$ & Cukup Baik \\
\hline Irritation & 3 & 4430 & 6030 & $73,46 \%$ & Baik \\
\hline Total & 15 & $\mathbf{2 2 0 4 8}$ & $\mathbf{3 0 1 5 0}$ & $\mathbf{7 3 , 1 2 \%}$ & Baik \\
\hline
\end{tabular}

Sumber: Pengolahan data, 2019.

Dari tabel ini terlihat bahwa total tanggapan responden terhadap native ads melalui variabel belief adalah 73,12\% (baik), artinya yaitu native ads mendapatkan kepercayaan (beliefness) yang baik pada responden. Selanjutnya adalah rekapitulasi attitude responden terhadap native ads pada tabel 3.

Tabel 3 Rekapitulasi Tanggapan Responden Terhadap Native Ads Melalui Variabel Attitute

\begin{tabular}{lcccc}
\hline \multicolumn{1}{c}{ Indikator } & $\begin{array}{c}\text { Total Skor } \\
\text { Aktual }\end{array}$ & $\begin{array}{c}\text { Total Skor } \\
\text { Ideal }\end{array}$ & Persentase & Kriteria \\
\hline Iklan sebagai hal yang baik & 1523 & 2010 & $75,77 \%$ & Baik \\
Iklan dianggap penting & 1426 & 2010 & $70,94 \%$ & Baik \\
Iklan disukai & 1525 & 2010 & $75,87 \%$ & Baik \\
Total & 4476 & 6030 & $74,19 \%$ & Baik \\
\hline
\end{tabular}

Sumber: Pengolahan data, 2019.

Total nilai attitude yang ditampilkan oleh responden sebesar 74,19\% (baik), artinya sikap responden positif dan menyukai native ads. Di bawah ini adalah Tabel 4 rekapitulasi behavior responden pada native ads.

Tabel 4 Rekapitulasi Tanggapan Responden Terhadap Native Ads Melalui Variabel Behavior

\begin{tabular}{lcccc}
\hline \multicolumn{1}{c}{ Indikator } & $\begin{array}{c}\text { Total Skor } \\
\text { Aktual }\end{array}$ & $\begin{array}{c}\text { Total Skor } \\
\text { Ideal }\end{array}$ & Persentase & Kriteria \\
\hline Clicking ads & 1437 & 2010 & $71,44 \%$ & Baik \\
See and read the ads & 1492 & 2010 & $74,22 \%$ & Baik
\end{tabular}


Siti Aisyah: Sikap Dan Perilaku Konsumen Terhadap Native Advertising 215

$\begin{array}{ccccc}\text { Search and visit the web } & 1406 & 2010 & 69,95 \% & \text { Baik } \\ \text { Total } & 4335 & 6030 & 71,89 & \text { Baik }\end{array}$

Sumber: Pengolahan data (2019)

Tabel tersebut memperlihatkan bahwa 71,89\% nilai responden yang click ads, artinya banyak responden yang mau mengunjungi iklan, membaca dan mengunjungi situs website iklan. Bahkan total nilai behavior responden terhadap native ads adalah $71,89 \%$ (baik).

\section{Model Testing}

Selanjutnya, hasil pengujian Structural Equation Model (SEM) berbasis varian (VBSEM) melalui Partial Least Square (PLS) menghasilkan dua tahap evaluasi pengukuran yaitu Outer Model dan Inner Model. Berikut adalah diagram jalur model belief, attitude and behavior toward display ads dalam penelitian ini.

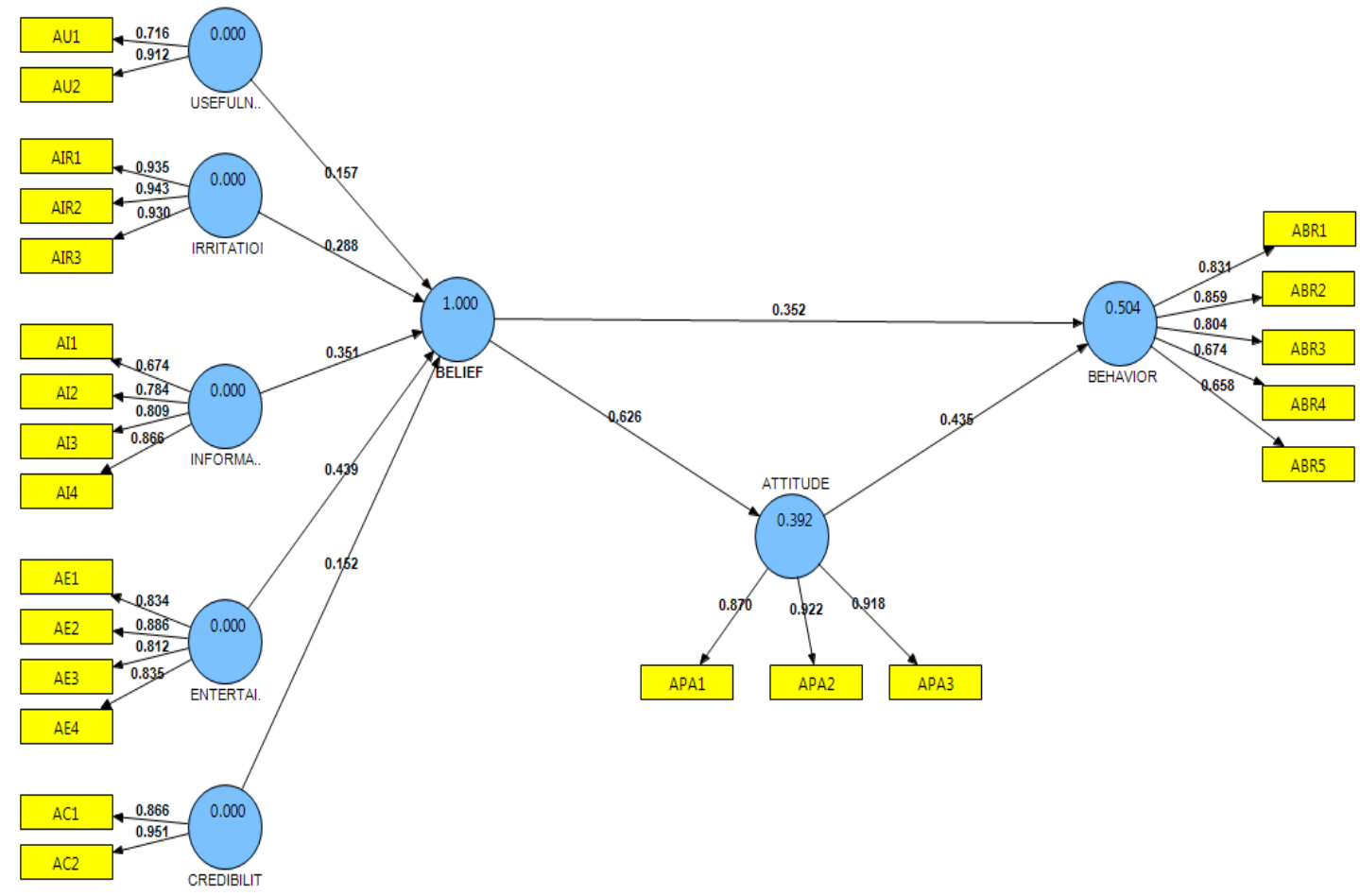

Gambar 2 Koefisien Standarisasi Model Persamaan Struktural Native Ads

Sumber: Pengolahan data, 2019.

Selanjutnya dilakukan pengujian convergent validity dengan menggunakan metode Loading Factor dan Variance Extracted (AVE). Hasil pengujian untuk masing-masing indikator variabel laten diuraikan pada tabel 5. di bawah ini: 
216 AT-TAWASSUTH: Jurnal Ekonomi Islam, Volume V No. 1

Januari - Juni 2020: 204 - 225

Tabel 5. Hasil Pengujian Loading Factor Native Ads

\begin{tabular}{|c|c|c|c|}
\hline $\begin{array}{c}\text { Variabel / Indikator } \\
\text { Variabel }\end{array}$ & $\begin{array}{l}\text { Loading } \\
\text { Factor }\end{array}$ & Indikator & Kesimpulan \\
\hline AI1 $\rightarrow$ Informativeness & 0,674 & $\geq 0,50$ & Valid \\
\hline $\mathrm{AI} 2 \rightarrow$ Informativeness & 0,784 & $\geq 0,50$ & Valid \\
\hline $\mathrm{AI} 3 \rightarrow$ Informativeness & 0,808 & $\geq 0,50$ & Valid \\
\hline $\mathrm{AI} 3 \rightarrow$ Informativeness & 0,866 & $\geq 0,50$ & Valid \\
\hline AU1 $\rightarrow$ Usefulness & 0,716 & $\geq 0,50$ & Valid \\
\hline AU1 $\rightarrow$ Usefulness & 0,911 & $\geq 0,50$ & Valid \\
\hline $\mathrm{AE} 1 \rightarrow$ Entertainment & 0,834 & $\geq 0,50$ & Valid \\
\hline $\mathrm{AE} 2 \rightarrow$ Entertainment & 0,886 & $\geq 0,50$ & Valid \\
\hline AE3 $\rightarrow$ Entertainment & 0,811 & $\geq 0,50$ & Valid \\
\hline $\mathrm{AE} 4 \rightarrow$ Entertainment & 0,835 & $\geq 0,50$ & Valid \\
\hline $\mathrm{AC} 1 \rightarrow$ Credibility & 0,865 & $\geq 0,50$ & Valid \\
\hline AC2 $\rightarrow$ Credibility & 0,950 & $\geq 0,50$ & Valid \\
\hline AIR1 $\rightarrow$ Irritation & 0,935 & $\geq 0,50$ & Valid \\
\hline AIR2 $\rightarrow$ Irritation & 0,942 & $\geq 0,50$ & Valid \\
\hline AIR3 $\rightarrow$ Irritation & 0,929 & $\geq 0,50$ & Valid \\
\hline APA1 $\rightarrow$ Attitude & 0,869 & $\geq 0,50$ & Valid \\
\hline APA2 $\rightarrow$ Attitude & 0,921 & $\geq 0,50$ & Valid \\
\hline APA3 $\rightarrow$ Attitude & 0,918 & $\geq 0,50$ & Valid \\
\hline ABR1 $\rightarrow$ Behavior & 0,830 & $\geq 0,50$ & Valid \\
\hline $\mathrm{ABR} 2 \rightarrow$ Behavior & 0,858 & $\geq 0,50$ & Valid \\
\hline ABR3 $\rightarrow$ Behavior & 0,804 & $\geq 0,50$ & Valid \\
\hline $\mathrm{ABR} 4 \rightarrow$ Behavior & 0,673 & $\geq 0,50$ & Valid \\
\hline ABR5 $\rightarrow$ Behavior & 0,658 & $\geq 0,50$ & Valid \\
\hline
\end{tabular}

Sumber: Pengolahan data, 2019.

Berdasarkan tabel 5 diatas diketahui bahwa semua item pertanyaan memiliki nilai Loading Factor diatas 0,5. Sehingga semua indikator dari construct variabel pada kuisioner dinyatakan valid. Setelah itu, dilakukan uji validitas (Average Variance Extracted atau AVE) dengan ketentuan jika konstruk memiliki nilai convergent validity $\geq 0.5$ maka dikatakan baik. 
Siti Aisyah: Sikap Dan Perilaku Konsumen Terhadap Native Advertising

Tabel 6 Hasil Pengujian AVE Native Ads

\begin{tabular}{lccc}
\hline \multicolumn{1}{c}{ Variabel / Indikator Variabel } & AVE & Indikator & Kesimpulan \\
\hline Informativeness & 0.618 & $\geq 0.5$ & Baik \\
Usefulness & 0.672 & $\geq 0.5$ & Baik \\
Entertainment & 0.709 & $\geq 0.5$ & Baik \\
Credibility & 0.826 & $\geq 0.5$ & Baik \\
Irritation & 0.876 & $\geq 0.5$ & Baik \\
Attitude & 0.816 & $\geq 0.5$ & Baik \\
Behavior & 0.592 & $\geq 0.5$ & Baik
\end{tabular}

Sumber: Pengolahan data, 2019.

Adapun nilai realibilitas (Composite Reliability atau CR) dianggap baik jika $\mathrm{CR} \geq 0.7$. Berikut hasil pengujian $\mathrm{CR}$ pada penelitian ini:

Tabel 7 Hasil Pengujian Composite Reliability Display Ads

\begin{tabular}{lccc}
\hline \multicolumn{1}{c}{ Variabel / Indikator Variabel } & $\begin{array}{c}\text { Composite } \\
\text { Reliability }\end{array}$ & Indikator & Kesimpulan \\
\hline Informativeness & 0,865 & $\geq 0.7$ & Reliabel \\
Usefulness & 0,801 & $\geq 0.7$ & Reliabel \\
Entertainment & 0,907 & $\geq 0.7$ & Reliabel \\
Credibility & 0,904 & $\geq 0.7$ & Reliabel \\
Irritation & 0,954 & $\geq 0.7$ & Reliabel \\
Attitude & 0,930 & $\geq 0.7$ & Reliabel \\
Behavior & 0,877 & $\geq 0.7$ & Reliabel \\
\hline
\end{tabular}

Sumber: Pengolahan data, 2019.

Pengujian selanjutnya yaitu uji nilai Cronchach's Alpha (CA) dengan ketentuan nilai $\mathrm{CA} \geq 0.6$ dianggap baik. Berikut hasil pengujian $\mathrm{CA}$ :

Tabel 8 Hasil Pengujian Cronchach's Alpha

\begin{tabular}{lccc}
\hline Variabel / Indikator Variabel & $\begin{array}{c}\text { Cronchach's } \\
\text { Alpha }\end{array}$ & Indikator & Kesimpulan \\
\hline Informativeness & 0,792 & $\geq 0.6$ & Reliabel \\
Usefulness & 0,736 & $\geq 0.6$ & Reliabel \\
Entertainment & 0,863 & $\geq 0.6$ & Reliabel
\end{tabular}


218 AT-TAWASSUTH: Jurnal Ekonomi Islam, Volume V No. 1

Januari - Juni 2020: 204 - 225

$\begin{array}{llll}\text { Credibility } & 0,800 & \geq 0.6 & \text { Reliabel } \\ \text { Irritation } & 0,929 & \geq 0.6 & \text { Reliabel } \\ \text { Attitude } & 0,887 & \geq 0.6 & \text { Reliabel } \\ \text { Behavior } & 0,827 & \geq 0.6 & \text { Reliabel }\end{array}$

Sumber: Pengolahan data, 2019.

Melalui pengujian dengan ketentuan $\mathrm{AVE} \geq 0.5, \mathrm{CR} \geq 0.7$ dan $\mathrm{CA} \geq 0.6$ artinya seluruh indikator dan variabel konstruk yang digunakan dalam penelitian ini valid dan reliabel sehingga dapat digunakan untuk menguji hipotesa dan model struktural (inner model). Selanjutnya dilakukan perhitungan R-Square untuk melihat berapa besar variabel belief dapat menjelaskan variabel konstruk attitude and behavior pada model penelitian display ads ini.

Tabel 9 Nilai R-Square Display Ads

\begin{tabular}{cc}
\hline Variabel Konstruk & Nilai $R$-square \\
\hline Attitude & 0,391 \\
Behavior & 0,504
\end{tabular}

Sumber: Pengolahan data, 2019.

Dari tabel 9 terlihat bahwa 39,1\% attitude factors dijelaskan oleh belief variable sedangkan 60,9\% dijelaskan oleh faktor-faktor lainnya. Behavior dijelaskan oleh belief variable sebesar 50,4\% dan 49,6\% dijelaskan oleh faktor-faktor lainnya. Lalu, dilakukan uji $Q$-square predictive relevance $\left(\mathrm{Q}^{2}\right)$ berikut:

$$
\begin{aligned}
& \mathrm{Q} 2=1-(1-\mathrm{R} 12)(1-\mathrm{R} 22) \ldots . .(1-\mathrm{RP} 2) \\
& \mathrm{Q} 2=1-(1-0,391)(1-0,504) \\
& \mathrm{Q} 2=0,697
\end{aligned}
$$

Melalui pengukuran $\mathrm{Q}^{2}>0$ maka model yang digunakan dalam penelitian ini memiliki nilai prediktif yang relevan dan dapat dilakukan pengujian hipotesis.

\section{Uji Hipotesis}

Uji hipotesis dilakukan dengan metode bootstrapping dengan bantuan aplikasi SmartPLS 2.0 sehinga diperoleh diagram jalur pengujian hipotesis sebagai berikut: 


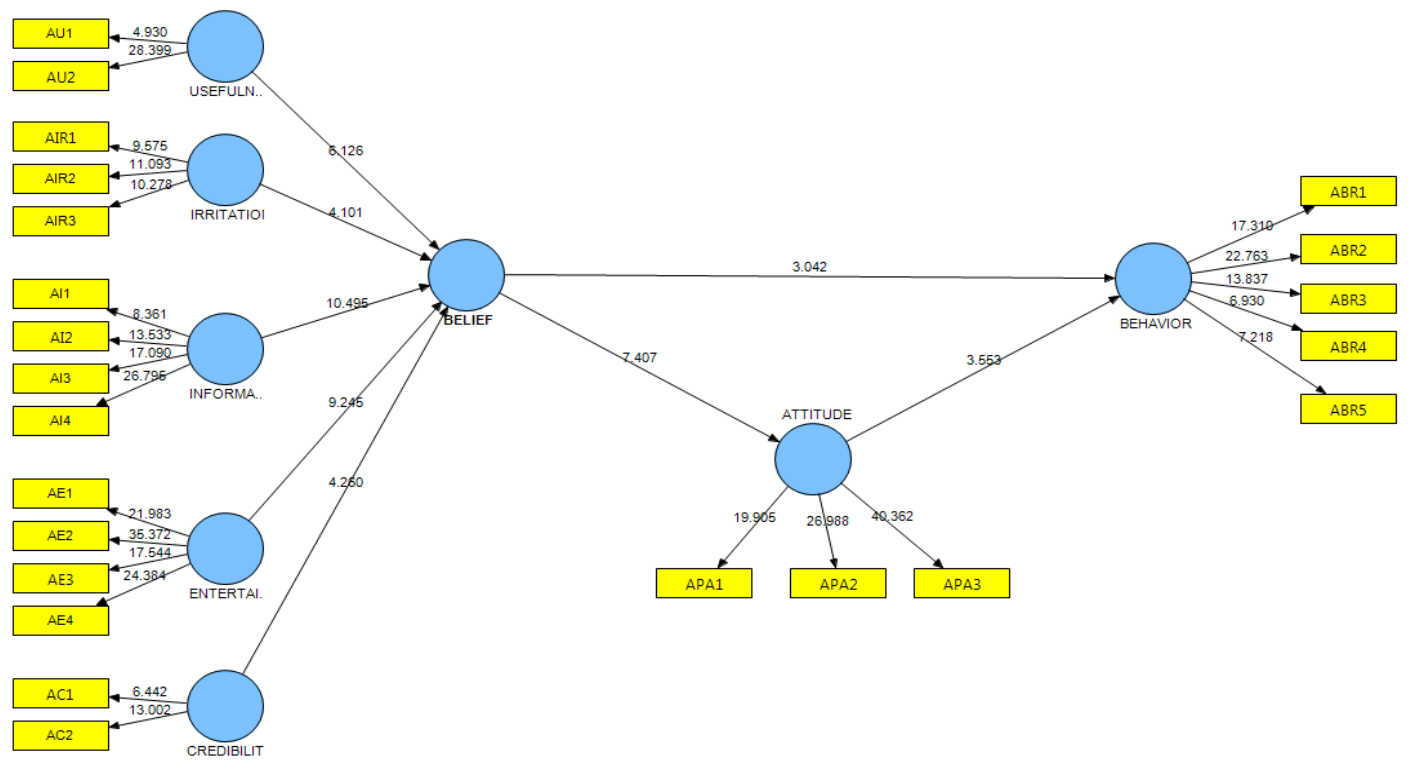

Gambar 3. Diagram Jalur Pengujian Hipotesa Native Ads

Sumber: Pengolahan data (2019)

Tabel 10. Hasil Pengujian Inner Weight Hipotesa Model Pada Native Ads

\begin{tabular}{cccccrr} 
Original & Sample & $\begin{array}{c}\text { Standard } \\
\text { Sample }\end{array}$ & $\begin{array}{c}\text { Mean } \\
\text { Deviation }\end{array}$ & $\begin{array}{c}\text { Standard } \\
\text { Error }\end{array}$ & $\begin{array}{c}\text { T } \\
\text { Statistics }\end{array}$ & \multicolumn{2}{c}{ Kesimpulan } \\
$($ O) & $(M)$ & $($ STDEV $)$ & $($ STERR $)$ & $(\mid$ O/STERR $)$ & & Ha
\end{tabular}

\begin{tabular}{|c|c|c|c|c|c|c|c|}
\hline $\begin{array}{l}\text { Ha }: \\
\text { Belief } \\
\text { berpengaruh } \\
\text { signifikan } \\
\text { terhadap } \\
\text { attitude } \\
\text { konsumen } \\
\text { pada display } \\
\text { ads } \\
\end{array}$ & 0,625 & 0,634 & 0,084 & 0,084 & 7,407 & Ditolak & Diterima \\
\hline $\begin{array}{l}\text { Ha }_{2} \text { : } \\
\text { Attitude } \\
\text { berpengaruh } \\
\text { signifikan } \\
\text { terhadap } \\
\text { behavior } \\
\text { konsumen } \\
\text { pada display } \\
\text { ads }\end{array}$ & 0,435 & 0,434 & 0,122 & 0,122 & 3,552 & Ditolak & Diterima \\
\hline $\begin{array}{l}\text { Ha3: } \\
\text { Belief } \\
\text { berpengaruh } \\
\text { signifikan } \\
\text { terhadap } \\
\text { behavior } \\
\text { konsumen } \\
\text { pada display } \\
\text { ads }\end{array}$ & 0,351 & 0,353 & 0,115 & 0,115 & 3,041 & Ditolak & Diterima \\
\hline
\end{tabular}


220 |AT-TAWASSUTH: Jurnal Ekonomi Islam, Volume V No. 1

Januari - Juni 2020: 204 - 225

Sumber: Pengolahan data (2019)

Uji F dan uji Anova dilakukan untuk membuktikan hipotesa $4\left(\mathrm{Ha}_{4}\right)$ dalam penelitian ini.

$$
\begin{gathered}
F_{\text {hitung }}=\frac{(n-k-1) R_{Y(\text { belief }, \text { attitude })}^{2}}{k\left(1-R_{Y(\text { belief,attitude })}^{2}\right)} \\
F_{\text {hitung }}=\frac{(402-3-1) 0,504}{3(1-0,504)} \\
F_{\text {hitung }}=134,8
\end{gathered}
$$

Dengan perhitungan R2 diperoleh Fhitung 134,80 dan uji Anova F-hitung sebesar 218.669 yang artinya dengan tingkat signifikansi 5\% diperoleh Fhitung > Ftabel sehingga Ha4 diterima.

Jika diperhatikan pada tabel 2 sampai dengan tabel 4 diketahui bahwa nilai belief, attitude dan behavior responden terhadap native ads baik, maka diindikasikan bahwa native ads efektif untuk digunakan atau Ha5 diterima.

Sebagaimana yang telah dideskripsikan dalam temuan penelitian di atas, semua hipotesis diterima. Hipotesa pertama (Ha1) yaitu belief berpengaruh signifikan terhadap attitude konsumen pada native ads diterima sebagaimana hasil pengujian thitung variabel belief terhadap attitude adalah sebesar 7,407 lebih besar dari ttabel yaitu 1,96. Karena thitung lebih besar dari ttabel diputuskan menerima Ha1 dan menolak H01. Artinya, penelitian ini menunjukkan bahwa tingkat kepercayaan konsumen (belief) terhadap native ads berpengaruh dalam menentukan bagaimana sikap (attitude) konsumen terhadap native ads sebagaimana yang telah disampaikan oleh Ducoffe, Wang, Zhang, Choi, Eredita, dan Boshoff bahwa beberapa indikator kepercayaan (belief) seperti informativeness, entertainment, irritation, credibility dan usefulness mempengarui bagaimana sikap konsumen (attitude). Dan dengan menggunakan tingkat kepercayaan 95\% dalam penelitian ini dapat disimpulkan bahwa belief memiliki pengaruh signifikan terhadap attitude. Hal ini mendukung penelitian-penelitian terdahulu yang dilakukan oleh Pollay and Mital, Wolin dan Saadeghvaziri. 
Pada penelitian ini, meskipun belief berpengaruh signifikan terhadap attitude namun analisa tanggapan responden menunjukkan bahwa attitude responden terhadap native ads yang dihasilkan kurang baik dan cenderung tidak disukai. Mayoritas responden menganggap native ads sangat mengganggu, tidak memberikan kebenaran informasi, tidak menghibur, tidak bermanfaaat dan tidak dapat dipercaya.

Hipotesa kedua (Ha2) dalam penelitian ini yaitu attitude berpengaruh signifikan terhadap behavior konsumen pada native ads adalah terbukti benar dengan hasil thitung 3,552 lebih besar dari ttabel yaitu 1,96. Dengan tingkat uji kepercayaan 95\% diketahui bahwa hubungan antara attitude dengan behavior sangat signifikan. Pada penelitian ini sikap yang terjadi adalah sikap baik terhadap native ads juga menghasilkan behavior baik dan menguntungkan. Berdasarkan hasil rekapitulasi tanggapan konsumen terlihat bahwa banyak responden yang memperhatikan native $a d s$, mengklik dan mengunjungi website pengiklan.

Hipotesa ketiga $\left(\mathrm{Ha}_{3}\right)$ yaitu belief berpengaruh signifikan terhadap behavior konsumen pada native ads diterima. Hal ini ditunjukkan melalui $\mathrm{t}_{\text {hitung }} 3,401$ yang lebih besar dari $\mathrm{t}_{\text {tabel }}$ yaitu 1,96 dan dengan tingkat uji kepercayaan 95\% dapat disimpulkan bahwa hubungannya sangat signifikan. Hasil ini sejalan dengan penelitian Pollay dan Mital (1993) bahwa beliefs berdampak kepada behavior.

\section{Kesimpulan}

Model dalam penelitian ini dapat dijadikan sebagai model untuk mempelajari bagaimana reaksi atau pengguna internet di Indonesia ketika mereka menemukan native ads saat menggunakan internet. Model ini juga dapat digunakan untuk mengukur efektifitas sebuah pesan atau iklan yang disampaikan. Penelitian ini menunjukkan bahwa nilai-nilai belief pada native ads pad umumnya bernilai baik dan positif. Sehingga, dapat disimpulkan bahwa native ads diterima dengan baik oleh audience.

\section{(Endnote)}

1 Nielsen, Belanja Iklan Digital Menyumbang Porsi 6\% Dari Total Belanja Iklan. Nielsen.com, diakses melalui https://www.nielsen.com/id/id/press-releases/2019/belanja-iklan-digitalmenyumbang-porsi-6-dari-total-belanja-iklan/

\footnotetext{
${ }^{2}$ IAB, Native Advertising Play Book 2. IAB.com. diakses melalui https://www.iab.com/wp-
} 
content/uploads/2015/06/IAB-Native-\%0AAdvertising-Playbook2.pdf.

${ }^{3}$ Melanie Deziel, Women Inmates: Why the Male Model Doesn't Work. diakses melalui https://www.nytimes.com/paidpost/netflix/women-inmates-separate-but-not-equal.html.

${ }^{4}$ Lieria Boshoff, A Comparative Study Between Native Advertising and Display Advertising on CNBCAFRICA.com. IEESpace Education Journal Database (2015), h.1

${ }^{5}$ P. Kotler dan K. L. Keller. Marketing Management 12e. (New Jersey, 2006)

${ }^{6}$ Ibid., h. 1

${ }^{7}$ R. Ducoffe. Advertising Value And Advertising On The Web, Journal of Advertising Research, Vol. 36 No. 5, 1996, h. 21-35.

${ }^{8}$ H. Russell, J. Staffaroni, and A. Fox. The Missing Measures Of Copy Testing, Journal of Advertising Research, Vol. 34 No. 3, 1994, h. 46-56.

${ }^{9}$ Ying Wang dan Shaojing Sun, Assessing beliefs, attitudes, and behavioral responses toward online advertising in three countries. International Business Review, Vol. 19 No. 4 (2010), h.344. https://doi.org/10.1016/j.ibusrev.2010.01.004

${ }^{10}$ Tankosic, A., \& Anita. Internet Marketing Communication and Schools: The Slovenian Case Study. Organizacija Journal of Management, Informatics and Human Resources, Vol 41. No.4, (2008), h. 136.

${ }^{11}$ D. Chaffey, F. Ellis-Chadwick, R. Mayer, dan K. Johnston. Internet Marketing: Strategy, Implementation And Practice. (Pearson Education, 2009)

${ }^{12}$ W. Wells, J. Burnett, S. E. Moriarty, R. C. Pearce, dan C. Pearce. Advertising: Principles and Practice (Vol. 328). Englewood Cliffs (NJ: Prentice Hall, 1989).

${ }^{13}$ Kasali, R. Manajemen Periklanan Konsep dan Aplikasinya, (Jakarta: PT Temprint. 2005), h. 11

${ }^{14}$ Kim, C., Kwon, K., \& Chang, W. How to Measure the Effectiveness of Online Advertising in Online Marketplaces. Expert System with Applications. ScienceDirect Online Education Journal Database, Vol 28 No 4, h. 4234

${ }^{15}$ Wasserman, Todd. (2012, 6 September). What is Native Advertising? Diakses melalui. www.mashable.com

${ }^{16}$ M. Manic. The Rise of native advertising. Bulletin of the Transilvania University of Brasov. Economic Sciences. Series V, 8(1), 2015, h. 53.

${ }^{17}$ Mareck, M. Native Advertising. Research World. Research World, 2014 No. 45, h. 23

${ }^{18}$ Campbell, C., \& Marks, L. J. Good Native Advertising Isn't A Secret. Business Horizons, Education Journal Database Vol. 58 No. 6, 2015, h. 600.

${ }^{19}$ Seligman, T. J. Native Advertising: The Old Is New Again. The Computer \& Internet Lawyer. Mondaq, February 2015, h. 1.

${ }^{20}$ Peter, J. P., \& Olson, J. . Perilaku Konsumen dan Strategi Pemasaran (Jakarta: Salemba Empat, 2014), h. 120

${ }^{21}$ Peter, J. P., \& Olson, J. C. Perilaku Konsumen dan Strategi Pemasaran, h. 122

${ }^{22}$ Jr, R. S. W., \& Albarracin, D. Belief Formation, Organization, and Change: Cognitive and Motivational Influences. 2014. h. 11 
${ }^{23}$ Ying Wang dan Shaojing Sun, Assessing beliefs, attitudes, and behavioral responses toward online advertising in three countries. h. 36

${ }^{24}$ Lieria Boshoff, A Comparative Study Between Native Advertising and Display Advertising on CNBCAFRICA.com, h. 1

${ }^{25}$ Ibid., h. 1

${ }^{26}$ Ibid., h.2

${ }^{27}$ Ibid., h. 2

${ }^{28}$ Ibid., h.299

29 Indrawan, R., \& Yuniawati, P.Metodologi Penelitian: Kuantitatif, Kualitatif, dan Campuran untuk Manajemen, Pembangunan, dan Pendidikan (Cetakan Ke-1). (Bandung: Refika Aditama, 2014), h.51.

\section{Daftar Pustaka}

Boshoff, L. (2015). A Comparative Study Between Native Advertising and Display Advertising on CNBCAFRICA. COM (Doctoral dissertation, The IIE).

Campbell, C., \& Marks, L. J. (2015). Good native advertising isn'ta secret. Business Horizons, 58(6), 599-606.

Chaffey, D., Ellis-Chadwick, F., Mayer, R., \& Johnston, K. (2009). Internet marketing: strategy, implementation and practice. Pearson Education.

Deziel, M. (2014). Women inmates: Why the male model doesn't work. The New York Times.

Ducoffe, R. (1996), “Advertising value and advertising on the web", Journal of Advertising Research, Vol. 36 No. 5, pp. 21-35.

Iab.com. (2013, 4 Desember). The Native Advertising Playbook: Six Native Ad Categories, Six Marketplace Considerations, And Iab Recommended Disclosure Principles. Diakses pada 25 Oktober 2019 dari https://www.iab.com/wp-content/uploads/2015/06/IAB-Native-AdvertisingPlaybook2.pdf

Indrawan, R., \& Yaniawati, P. (2014). Metodologi Penelitian Kuantitatif, Kualitatif, Dan Campuran Untuk Manajemen, Pembangunan, Dan 
Pendidikan. Bandung: PT Refika Aditama.

Kasali, R. (2005). Manajemen Periklanan: Konsep dan Aplikasinya di Indonesia, Cet. V, Jakarta: PT Temprint.

Kim, C., Kwon, K., \& Chang, W. (2011). How to measure the effectiveness of online advertising in online marketplaces. Expert Systems with Applications, 38(4), 4234-4243. ${ }^{29}$ Mareck, M. Native Advertising. Research World. Research World, 2014 No. 45, h. 23

Kotler, P., \& Keller, K. L. (2006). Marketing management 12e. New Jersey.

Manic, M. (2015). The Rise of native advertising. Bulletin of the Transilvania University of Brasov. Economic Sciences. Series V, 8(1), 53.

Nielsen.com. (2019, 18 September). Belanja Iklan Digital Menyumbang Porsi 6\% Dari Total Belanja Iklan. Diakses pada 25 Oktober 2019, dari https://www.nielsen.com/id/id/press-releases/2019/belanja-iklan-digitalmenyumbang-porsi-6-dari-total-belanja-iklan/

Peter, J. P., \& Olson, J. C. (2014). Perilaku Konsumen \& Strategi Pemasaran. Jakarta: Salemba Empat.

Russell, H., Staffaroni, J. and Fox, A. (1994), "The missing measures of copy testing”, Journal of Advertising Research, Vol. 34 No. 3, pp. 46-56.

Seligman, T. J. (2015). Native advertising: The old is new again. The Computer \& Internet Lawyer, 32(7), 1-9.

Tankosić, A., \& Trnavčevič, A. (2008). Internet marketing communication and schools: The Slovenian case study. Organizacija, 41(4).

Wang, Y., \& Sun, S. (2010). Assessing beliefs, attitudes, and behavioral responses toward online advertising in three countries. International Business Review, 19(4), 333-344. https://doi.org/10.1016/j.ibusrev.2010.01.004

Wasserman, Todd. Sep. 26, 2012. What is Native Advertising?. www.mashable.com Wells, W., Burnett, J., Moriarty, S. E., Pearce, R. C., \& Pearce, C. 
(1989). Advertising: Principles and practice (Vol. 328). Englewood Cliffs, NJ: Prentice Hall.

Wyer Jr, R. S., \& Albarracín, D. (2005). Belief Formation, Organization, and Change: Cognitive and Motivational Influences. 